\title{
Strategy to Prevent the Risk of Trading in Binary Options
}

\author{
María Elena Espín Oleas, Mariela Elizabeth Arévalo Palacios \\ Escuela Superior Politécnica de Chimborazo, Riobamba, Ecuador
}

\begin{abstract}
The world of the trading offers a group of very structured economic rules starting from which it is operated in bag or in binary options being that bigger risk represents for the investment. However, to diminish this risk will depend on the experience and the knowledge that he/she has the operator in the transaction type that he/she carries out or want to make. The binary options are a financial product on an underlying assets or support and it indicates it understands of $50 \%$ of probabilities of loss and $50 \%$ of gain probabilities, what understands each other like a relationship 1:1. The knowledge of this type of operations makes that its traders get interests in short time; however, not to know how the market works; it bears to losses exaggerated and possible swindles. The article develops a strategy to diminish the risk in these transactions, based on a bibliographical revisation, statistic, with a qualitative methodology, investigation-action that involves the actions that he/she will be able to develop a trader to mitigate the risk of its transactions, with the objective of maintaining the investment in rise, and with a minimum opening capital and without significant losses.
\end{abstract}

Keywords: binary options, risk, trading, strategy

\section{Introduction}

The financial world is one of the fields where major innovations are emerging, as a result of the maturity and perfection of the markets. However, investments will always have the fundamental characteristic: A higher risky return will be investment and, conversely, if profitability is lower, the risk will be low; establishing this fundamental relationship, we enter the world of trading. Trading is understood as a technique of bets or investments derived from the stock markets, which is based on taking advantage of fluctuations in the prices of the underlying assets and is strictly structured (Alonso, 2014). Trading can be done both for the stock market in the direct acquisition of an asset or it can be done within the binary options; the people who carry out this type of transaction are known as traders or operators who may be the owners of the capital or qualified traders who will be the intermediaries between the investors and the investment platforms or brokers. $^{1}$

On the other hand, binary options are among the fastest growing investment sectors and it is especially popular for its simplicity and the possibility of a large increase in value. In a very short time, the value of your

\footnotetext{
María Elena Espín Oleas, Ph.D., profesor, Applied Academic Research, Escuela Superior Politécnica de Chimborazo, Riobamba, Ecuador.

Mariela Elizabeth Arévalo Palacios, Ingeniería Financiera, Applied Academic Research, Escuela Superior Politécnica de Chimborazo, Riobamba, Ecuador.

Correspondence concerning this article should be addressed to María Elena Espín Oleas, Ciudadela Cemento Chimborazo, Manzana F. Casa 2 Street Manuela Sáenz, Riobamba 060150, Ecuador.

1 Serrano, F. Qué es el trading? Finanzas.com. [En línea] Citado el: 13 de Octubre de 2014. Disponibloe en: http://www.finanzas.com.
} 
resources can rise by a very high percentage. However, not having a true and experimental knowledge in this type of options is a source of risk that accumulates, for investors, bad experiences.

The valuation of operations arises at the beginning of the 20th century with the doctoral thesis on Bachelor's theory that discussed speculation. However, in 1996, Bonness suggests a formula similar in nature to that of Black and Sholes but based on an unknown interest rate that included compensation for the risk associated with the share price. After nine years, the formula for the price of a European purchase option that was written on an action is derived. By 1975, this formula was already widely used in the Chicago Edge Options Exchange, the first exchange to use options since 1973. Subsequently, Merton analyzes the valuation of derivatives assuming more complex stochastic processes for the price of the underlying asset, such as discontinuities. For the development of this theory, Scholes and Merton were awarded the Nobel Prize in economics in 1997 (Black \& Scholes, 1972).

Since the 80's, Hull (1987), Rubinstein (1991), White (1992), and among others have worked on the valuation of the so-called "exotic options". Likewise, Trigeorgis (1996), Brennan and Schwartz (1985), and others have illustrated how the theory of options can be used in the valuation of investment projects of real options. Other applications of the theory of options found in the literature are the valuation of warrants fixed income instruments (Villamil, 2016; White, 1987).

Currently, Binary Options Theory has become one of the main reference points in the conception and development of modern financial markets. Probably the illustrious Fisher Black, Myron S. Scholes, and Robert C. Merton ${ }^{2}$ were not aware that with their academic works of reference, three decades ago, they were sowing the conceptual seed of a theory that has revolutionized the world of finance for its undoubted applications in the field of financial innovation, valuation of investments, corporate finance and currently in the actuarial field. During all this time, the derivative markets have developed remarkably and for this to happen, there have been numerous and tremendously valid contributions that have been used from the academic world. ${ }^{3}$

Binary options, also known as digital options, are option contracts where the payment of the underlying asset is fixed and exceeds the predetermined exercise price within a set period without the obligation to buy the asset. The payment of the option does not depend on the magnitude in which the price of the underlying asset moves. Bearing in mind that as an underlying asset, asset is known that is used as a basis for contracting in derivative markets, being these not only physical but also financial, such as an interest rate or an exchange rate; an index value, either with fixed or variable income; or a reference credit (Overby, 2009). In simple terms, binary options allow a person to invest in an asset and it returns a certain percentage as a profit (Píngaro, 2016; Kauffman, 1998).

The main types of binary options known are cash or nothing or assets or nothing, where the binary option of cash or nothing pays a fixed amount of cash if the option expires in the money. On the other hand, if the asset option expires out of the money, "out the money" will not pay anything the value of the underlying title. There are options in interest rate markets (most common in Forex) and fixed income options (in the American Stock Exchange). Another type is the call and put where with a call option allows the buyer to participate in market increases above a price stipulated by the same until the expiration of the contract. The buyer of a call

\footnotetext{
2 Merton, R. Option pricing when the variance is changing. [En línea] [Citado el: 12 de Febrero de 2018.] http://www.dii.uchile.cl/ ceges/publicaciones/ceges16.pdf.

3 Fernández, Viviana. Teoría de opciones: una síntesis. [En línea] [Citado el: 12 de Febrero de 2018.] http://www.dii.uchile.cl/ ceges/publicaciones/ceges16.pdf.
} 
option has a potential gain linked to the advantages of the increases in the underlying asset whereas a put option gives the buyer the right to participate in the decreases of the underlying asset below a price stipulated by it until the expiration of the contract. The buyer of a put option has considerable potential gain in the event of a fall. There are also touch-without-touch options where the aim is to predict whether the price of the asset being worked on will reach a value selected by the broker at some time before the expiry time, in case the prediction is correct. Correct returns will be obtained between $70 \%$ and $95 \%$ depending on the broker and the underlying asset (Kauffman, 1998; Wilmott, 1995).

Thanks to these options, the investment has become more comprehensible for all the public without discrimination due to their capital or sufficient business experience to trade in classic exchanges. In this industry, each trader knows the potential of the gains and losses beforehand and cannot invest having debts, which means that he/she will never lose more money than he/she has invested. However, the volatility of prices in the underlying assets will determine whether the investor adopted a correct strategy to allow his/her investment to grow or if, on the contrary, he/she lost his/her initial capital (Montero, 2014). It takes into account the volatility of the market and therefore the risk that represents when it comes to predicting the price of an asset, so establishing a strategy is essential since there are specific general actions that can be taken before starting with this type of financial operations, at the same time that the risk reduction in the trading of binary options can generate confidence in future investors.

The work is developed under a bibliographic review and the construction of a strategy based on this technical study, with a direct application for two types of assets in two different times, in order to establish the value of the strategy, considering the advantages and limitations and what is wrong with it.

\section{Methodology of the Strategy}

Before implementing a strategy to reduce the risk of trading, it was taken into account that financial transactions in any type of market will always be or will be carried out under norms or international laws that try as much as possible to regulate the speculation and risk of investments. For the year 2008, it is dictated by the stock markets, that traders for binary options can act alone without a guaranteed broker, so the main and only responsible will be who manages the account or will be the owner of the capital invested.

To present a strategy to reduce risk in the trading of binary options, a study was carried out with a qualitative research and action methodology whose instrument is the statistical analysis of the European Financial Markets Directive (MiFID) located in Cyprus, Malta (Pring, 1991) and the different bibliographical works of several authors.

So, a strategy to reduce the risk of trading that investors have follows the following actions:

\section{Conduct a Technical Examination}

It is based on performing an operation through signals by oscillators and technical indicators, such as moving averages that will indicate the possible movement of the price of a financial asset. The technical analysis also uses chartism, which consists in the study of the graph to forecast the future behavior of the different financial assets, based on lines and geometric figures, among the best known, the shoulder-head-shoulder, double top, and double soil ${ }^{4}$.

\footnotetext{
${ }^{4}$ Ossa, Matías. Análisis técnico de indicadores bursátiles. [En línea] [Citado el: 12 de febrero de 2018.] Disponible en: http://inbestia.com.
} 
Indicators. Simple Mobile Average (SMA). The Simple Moving Average or SMA is the average price for a given period of time (five minutes, one hour, and one day) where each of the periods chosen has the same importance over the average.

Average Directional Index (ADX). The ADX indicator measures the strength or quality of the trend and if there is a particular direction in the market, the ADX moves on a scale of 0 to 100 and has a horizontal line at level 20. In general, a reading above 25 can be considered directional. Keep in mind that what the ADX tells us is only the strength of the trend and not its direction. For example, if the price falls and the ADX technical indicator is rising, then it means that the bearish trend is significant (Técnicas De Trading, 2016).

William's \% R. The William's \% R indicator shows the current closing price in relation to the ups and downs of the last determined days. The William's \% $\mathrm{R}$ is measured on a negative scale between -100 (bottom point) to 0 (the top point). William's $\% \mathrm{R}$ is a moment indicator that measures the levels of excess purchases and excess sales. The Williams uses a 10-day trading period and if it is below -80 , it is considered as an excess sales level, while a reading higher than -20 is considered as an excess of purchases (Aan, 1985).

\section{Review Patterns of Return}

The return pattern is used by many analysts to determine the movement of an asset, sector, or market.

Indicators. Roc exchange rate.

Tasa de cambio Roc $=C c n * 100$

where: $C$ is the last closing price, $n$ predetermined number of days, and $c$ closing price of " $n$ " previous days.

Parabolic indicator SAR. It is mainly used to determine the future short-term price of the trend of a certain financial asset. The parabolic SAR indicator allows traders to determine stop loss orders. The parabolic SAR graph is a series of points placed above or below the price. The points are below the price when the asset trend is bullish, while the points are above the price when the trend is bearish. The signals are generated when the position of the points changes direction and are placed on the opposite side of the price ${ }^{5}$.

$$
S A R m a n ̃ a n a=S A R h o y+A F *(\text { EPtrade }- \text { SARhoy })
$$

where: EPtrade End point of the section. If you are in a long position, you are buying, then it is the maximum reached during the operation. On the contrary, if it is at the lowest minimum reached during the operation,

$\mathrm{AF}=$ Default acceleration factor is 0.02 with a maximum of 0.2 .

Bollinger Bands. The Bollinger Bands are drawn by two lines: One is higher than the simple moving average and the other lower. The Bands indicate a sale when they are above the moving average (or near the upper band-excess market of purchases) and indicate a purchase when the Bands are below the moving average (or near the lower band-market in excess of sales). It is important to keep in mind that the bands reflect price volatility (Wilder, 1978). The basic interpretation of the Bollinger bands is that prices tend to remain between the upper and lower bands. The characteristic of the Bollinger Bands is that the space between the bands varies according to the volatility of the prices. In times of greater volatility in the market, the bands will be wider, and during periods of low volatility, the bands narrow in order to contain the prices of currencies.

\section{Compare Prices of the Underlying Assets in the Different Time Intervals}

Indicators. Fibonacci. Investors who implement the Fibonacci Model in financial markets use it to

\footnotetext{
${ }^{5}$ Neilsen, s. Soren y k. Programming Languages and Systems in Computational Economics Ant Finance. [En línea] [Citado el: 12 de febrero de 2018.] Disponible en: http://scholar.goggle.com.ec.
} 
determine how much the price of a given financial asset could rebound or fall back. The concept of Fibonacci involves a series of setbacks based on mathematical relationships that originate from natural phenomena and psychological factors, linked to those who participate in the market. Fibonacci retracements allow us, during the development of a correction to a previous movement, to establish a priori levels of support or resistance where we can expect a turn. The most popular Fibonacci levels or ratios are 23.6\%,38.2\%, 50\%, 61.8\%, 100\%, and $161.8 \%$. Fibonacci retracements are displayed by selecting two extreme points of a graph. They are normally applied to tranches in which the market has shown a tendency, and they are used to detect the levels at which the price, when going back, bounces back to resume the same trend (Grazziano, 2015).

Momentum indicators. Momentum indicators determine the vitality of a trend over time. The Momentum shows itself strongly when the trend begins, and then weakens when the trend changes.

$$
\mathrm{M}=\mathrm{C}-\mathrm{Cn}
$$

where: $M$ being the moment, $C$ the last previous quote in $n$ days to which we take as reference ${ }^{6}$.

\section{Review the Time Available to Carry out the Operations}

\section{Indicators.}

Short term: between 5 and 49 sessions.

Medium term: between 50 and 90 sessions.

Long term: between 100 and 200 sessions, indicating the primary trend.

\section{Review the Economic Calendar}

Indicators. Relative Strength Index. Measures the force how the supply and demand acts, expressed as a percentage

$$
\text { Fuerza relativa }=100-(1001+r s) \text { con } \operatorname{rs} A n B n
$$

where: An Average of the price variations that were positive for the last $n$ periods. $B n$ Average of the price variations that were negative for the last $n$ periods.

\section{Choose the Currencies, Commodities, Indices, Stocks}

Indicators. Stochastic. Stochastic is used to indicate situations of excess purchases and excess sales on a scale of $0-100$. This indicator is based on the observation that in an uptrend, prices tend to rise towards the day's highs. On the contrary, when prices fall and the trend is bearish, prices tend to approach the minimum of the day. Stochastic calculations produce two lines, namely $\% \mathrm{~K}$ and $\% \mathrm{D}$. These are used to indicate situations of excess purchases and sales (Pring, 1991).

Exponential Moving Average (EMA). This indicator gives more importance to the latest quotes with respect to the total average. For example, in a 20-day EMA, the last 10 days will have more effect on the average than the first 10 days. The objective is to use the most recent data to better visualize the trend.

$$
\text { Phoyxk + EMAayer }(1-k)
$$

where: EMA: Exponential moving average, EMAyetrday The exponential moving average of yesterday, Today's price, $\mathrm{N}=$ number of days in the exponential average, $\mathrm{K}=2 /(\mathrm{N}+1)$.

Convergence Divergence of Moving Average (MACD). This indicator consists of the drawing of two lines. The MACD line is the difference between two exponential moving averages and the trigger line is an exponential moving average of the difference. If the MACD lines cross, then it is taken as a sign that a change

\footnotetext{
${ }^{6}$ Oksendal, B. Sthochastic differential Equations. An introduction with applications. [En línea] [Citado el: 12 de febrero de 2018.] Disponible en: http:// scholar.goggle.com.ec/scholar?q=oksendal+stochastic+differential.
} 
in trend is very likely (Costa, 1992; Hull, 2004).

$$
M A C D=E M A\left(n^{\circ} \text { minor of periods }\right)-\left(n^{\circ} \text { greater periods }\right)
$$

\section{Identify the Graphics}

Study the daily trend graphs of different financial assets and perform operations only with financial assets have a clear trend in LOW or LOW, if the trend is not clear, which seems to follow the financial asset is better to wait and not perform any operations ${ }^{7}$ (Wilder, 1978).

Upward trend (increase in the value of the asset), Downward trend (decrease in the value of the asset), and Neutral trend (stability in the value of the asset) are identified in Figure 1.

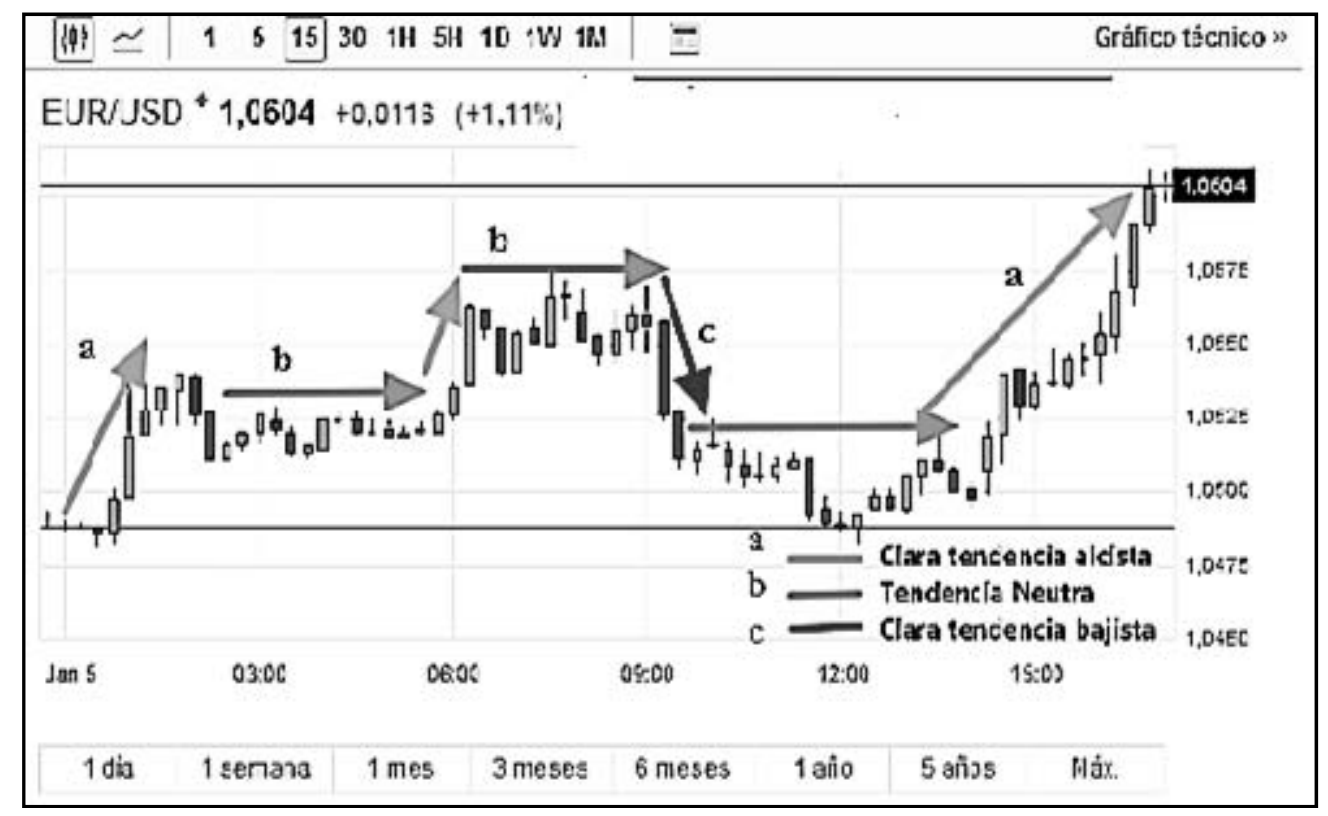

Figure 1. Trend graphs.

\section{Choose a Safe Broker}

The choice is reduced to five brokers. It is important to raise the appropriate questions to define which corridor will best respond to the requirements of each to negotiate (Aan, 1985). In case, the minimum amounts are very important then to open a binary option transaction with a small budget, it is advised that you select a broker with a minimum deposit reduced, minimum amount of minimum position and with a tempting bonus. If you want to take advantage of the return on investment, you must select the broker with the best return or maximum profit expressed in percentage (\%) (Appel \& Zweig, 1976).

Finally, if the main objective is to increase the starting balance to start with more money in order to increase the size of the positions or minimize the risks and optimize the management of the capital, it is advisable to choose the broker with the best bond in the first deposit with real money, as well as the percentages of benefit and the form of payment that the broker will carry out.

Indicators. The TRUSTe Certified Privacy seal on a page or application indicates that the operating company complied with the established liability requirements.

The Norton ${ }^{\mathrm{TM}}$ Secured seal and Symantec Seal-in-Search guarantee customers that it is safe to browse,

$\overline{7}$ Biayna, A. Operaciones Financieras. [En línea]. [Citado el: 12 de febrero de 2018.] Disponible en: www.books.google.ec. 
search, and buy.

The most used and guaranteed brokers are: Iq Option, Poloniex, Binary.com, Markets, Binomo, and BDSwiss.

\section{Carry out the Operation in the Chosen Broker}

The operation is performed with the exposed steps. In case of further reducing the risk of capital to invest, it is recommended to do a simulation before, which means without a real capital bet, generating experience in the investor.

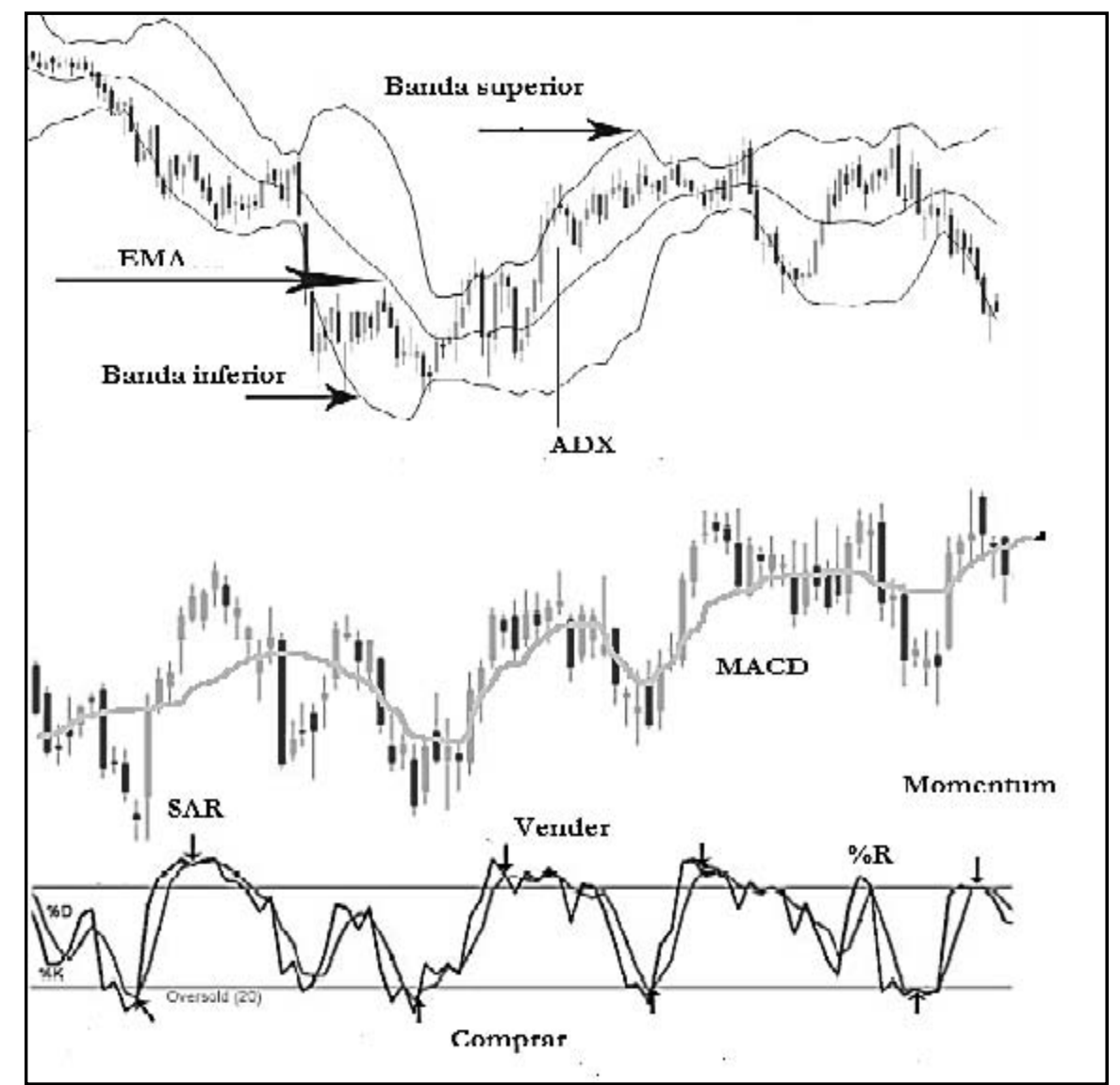

Figure 2. Methodology of the Strategy. Note. The figure shows the indicators graphically to be able to recognize them within the platform and when to buy and sell the option.

\section{Deductions From the Proposed Strategy}

Although binary options are a financial instrument that is easy to execute and accessible to all types of investors, it is not used as it is considered a scam and therefore a risk for investment with a percentage of $56 \%$; the second reason is the issue of education or technical way of applying it represented with $20 \%$, the third reason is the amount of investment, which is generally high in the stock market, with $14 \%$ and the final $10 \%$ ignorance of these options, as identified in Figure 3. 


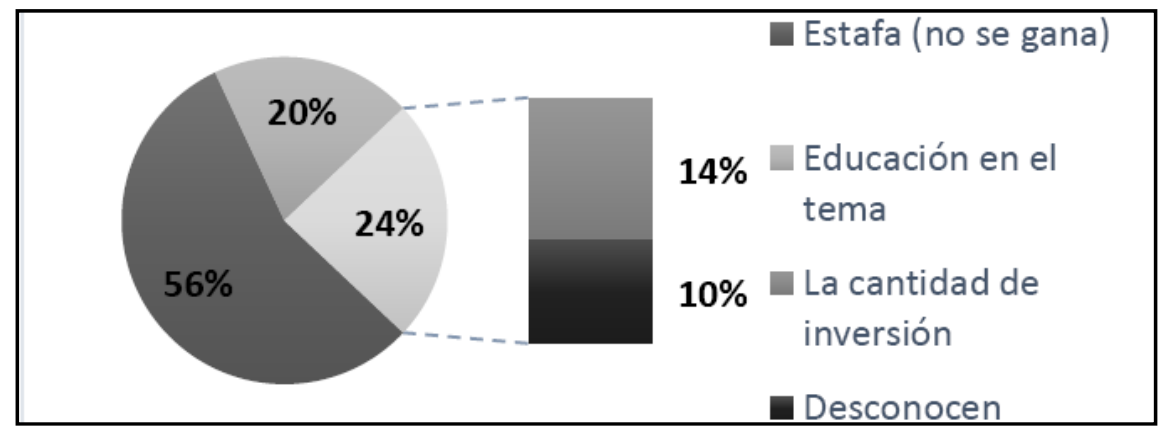

Figure 3. Why do not people invest in binary options? Statistics Malta-Cyprus Perception 2016 (456 Investors).

Analyzing the representative percentage in this statistic, it is deduced that investors consider a scam to invest in binary options, justifying with the amount of times they lose in the bet on the prices of the assets. However, it should not be considered a scam when losing, in these options, but rather that an adequate analysis was not carried out or there was not an adequate strategy for predicting the price of the assets that were chosen (Dotson, 2016; Cofnas, 2016). This statistic is substantial in the development of the proposed strategy as it justifies the creation of the same and in turn contributes to future investors incursion in binary options, as it reduces the risk of loss and educates on the subject; being able to cover the main percentages of this statistic.

The proposed strategy consists of nine actions (see Table 1), the same that involves human resources, time, and materials, which point to a trading that is not based on fortune-telling, but of an authentic systematic, methodical, and disciplined behavior of tracking and interpretation of multiplicity of variables related to assets that generate more expectations in the market or directly to the investor.

Table 1

Strategy to Reduce the Risk of Trading in Binary Options

\begin{tabular}{|c|c|c|c|}
\hline Acctions & Indicators & Time & Materials \\
\hline Conduct a technical exam & $\begin{array}{l}\text { Promedio Móvil Simple (SMA) } \\
\text { ADX } \\
\text { William's \% R }\end{array}$ & 3 horas & $\begin{array}{l}\text { Computador } \\
\text { internet }\end{array}$ \\
\hline Review patterns of return & $\begin{array}{l}\text { Tasa de cambio Roc } \\
\text { Indicador parabólico SAR } \\
\text { Bandas de Bollinger } \\
\end{array}$ & 2 horas & $\begin{array}{l}\text { Computador } \\
\text { internet }\end{array}$ \\
\hline $\begin{array}{l}\text { Compare prices of the underlying assets in } \\
\text { the different time intervals }\end{array}$ & $\begin{array}{l}\text { Fibonacci } \\
\text { Indicadores Momentum }\end{array}$ & 1 hora & $\begin{array}{l}\text { Computador } \\
\text { internet }\end{array}$ \\
\hline $\begin{array}{l}\text { Review the time available to perform } \\
\text { operations }\end{array}$ & $\begin{array}{l}\text { Corto plazo: entre } 5 \text { y } 25 \text { sesiones. } \\
\text { Mediano plazo: entre } 50,70 \text { sesiones. } \\
\text { Largo plazo: } 100,200 \text { sesiones, indican la tendencia } \\
\text { primaria. }\end{array}$ & 1 hora & $\begin{array}{l}\text { Computador } \\
\text { internet }\end{array}$ \\
\hline Review the economic calendar & Índice de Fuerza relativa & 30 minutos & $\begin{array}{l}\text { Computador } \\
\text { internet }\end{array}$ \\
\hline Choose the type of underlying asset & $\begin{array}{l}\text { Estocástico } \\
\text { Convergencia Divergencia de Media Móvil (MACD) } \\
\text { Promedio Móvil Exponencial (EMA) }\end{array}$ & 30 minutos & $\begin{array}{l}\text { Computador } \\
\text { internet }\end{array}$ \\
\hline Identify the graphics & Tendencia alcista, bajista neutral, Velas japonesas & 1 hora & $\begin{array}{l}\text { Computador } \\
\text { internet }\end{array}$ \\
\hline Choose a safe broker & $\begin{array}{l}\text { Certificados: } \\
\text { TRUSTe } \\
\text { NORTON } \\
\end{array}$ & 1 hora & $\begin{array}{l}\text { Computador } \\
\text { internet }\end{array}$ \\
\hline \multirow[t]{2}{*}{ Perform the operation in the chosen broker } & Iq option & 1 hora & $\begin{array}{l}\text { Computador } \\
\text { internet }\end{array}$ \\
\hline & Total Horas Requeridas & 11 horas & \\
\hline
\end{tabular}


Applying the strategy, the following results were achieved:

The strategy for underlying financial assets was applied: stock indexes and cryptocurrencies or cryptocurrencies, currently assets that generate higher expectations among investors. Taking into account that there were data collected from operations in binary options without a strategy, in the broker IQ Option. For the stock indices, one-day periods were chosen to determine the price with upward and downward trends, being able to compare percentage results of effectiveness, when incurring in the market without a strategy and with the proposed strategy. Without a strategy, the effectiveness in hits with a downward trend reached $7.2 \%$, and for the upward trend, 9.6\%; On the other hand, the losses were down $40 \%$ and for the rising trend, $43.2 \%$. The percentages for the proposed strategy reached in hits with the downward trend $29 \%$ and $22 \%$ in the upward trend, while the misses were in a downward trend $31 \%$ and $18 \%$ for the upward trend. Reducing the risk in a $33.6 \%$ percentage also shows the effectiveness obtained by applying a strategy in this type of operations, as shown in Table 2.

For cryptocurrencies, 30-minute periods were chosen to determine the price with upward and downward trends, being able to compare percentage results of effectiveness, when incurring in the market without a strategy and with the proposed strategy. Without a strategy, the effectiveness in hits with a downward trend reached $10.4 \%$, and for the uptrend, $6.4 \%$; On the other hand, the losses were downward trend with $38.4 \%$ and for the upward trend $44.8 \%$. The percentages for the proposed strategy reached in success with the downward trend by $17 \%$ and $14 \%$ in the upward trend, while the errors were downward trend $38 \%$ and $31 \%$ for the upward trend. Achieving a decrease in risk by $14.4 \%$ also shows the effectiveness obtained by applying a strategy in this type of operation, as shown in Table 3.

It can be interpreted that the difference between the percentages reached in the two types of assets and with different periods is large, while in the indices, a $36 \%$ is achieved in the cryptocurrencies; a difference of $16 \%$ can be considered by the following factors:

(1) The periods of time chosen;

(2) The high volatility of the cryptocurrency market;

(3) The new market that these assets represent;

(4) The inexperience of the investor in the cryptocurrency market;

(5) Trends that are not very readable and difficult to interpret in the study of graphics.

However, it is laudable that the strategy manages to fulfill the objective for which it is proposed that it is the risk reduction in the binary operation. On average, you get $25.5 \%$ more in hits for the two trends, managing to safeguard the capital invested.

It is important to point out that the trading strategy for binary options that will give the greatest return will be the double investment since it guarantees $100 \%$ success, although with less benefit; it consists of investing in two different accounts, where the first will be the high-trend bet and the other the low price. Although this strategy is within the legal framework, it should be applied when a binary bonus is available, since this element will be the only one that increases the profit even if it is not secure.

The advantages of applying this strategy are directly linked to the technical knowledge that an investor will have to bet on binary options. At the same time, using this strategy contributes to the fact that the investment time is getting shorter and shorter, since it will be possible to operate with greater confidence even with the 60 second options, appealing to the investor's experience, while avoiding unnecessary mistakes. 
Among the limitations of the strategy there is the high volatility of the market for which there is no strategy that can correct this characteristic of the market. The investor's experience is crucial to improve predictions.

It is significant to investigate and educate yourself so that you can use your own strategy in order to invest in financial options.

It is recommended to use binary options as financial transactions and not as a game of chance. It must be constant with the time chosen to do the operations.

Tabla 2

Efectividad de las Operaciones Realizadas con Índices Bursátiles

Effectiveness of the Investment

\begin{tabular}{|c|c|c|c|c|c|}
\hline \multirow{3}{*}{$\begin{array}{c}\text { Bróker } \\
\mathbf{N}^{\circ} \text { de Sesiones } \\
\end{array}$} & \multicolumn{2}{|c|}{ Without strategy } & \multicolumn{2}{|c|}{ With strategy } & \multirow{4}{*}{$\begin{array}{c}\text { Results } \\
\text { Graph }\end{array}$} \\
\hline & \multicolumn{2}{|c|}{ IQ Option } & \multicolumn{2}{|c|}{ IQ Option } & \\
\hline & \multicolumn{2}{|c|}{125} & \multicolumn{2}{|c|}{125} & \\
\hline Active & \multicolumn{2}{|c|}{ stock indices } & \multicolumn{2}{|c|}{ stock indices } & \\
\hline Time & \multicolumn{2}{|c|}{1 day } & \multicolumn{2}{|c|}{1 day } & \\
\hline \multirow{2}{*}{ Low Trend } & hit & not right & hit & not right & \\
\hline & 9 & 50 & 39 & 36 & \\
\hline Effectlveness $\%$ & $7.2 \%$ & $40.0 \%$ & $31 \%$ & $29 \%$ & \\
\hline High Trend & 12 & 54 & 27 & 23 & \\
\hline Effectiveness $\%$ & $9.6 \%$ & $43.2 \%$ & $22 \%$ & $18 \%$ & \\
\hline \multicolumn{3}{|c|}{ Difference $\%$ with the strategy used } & $36.0 \%$ & $-36.0 \%$ & \\
\hline
\end{tabular}

Table 3

Effectiveness of the Operations Carried out With Cryptocurrencies

Effectiveness of the Investment

\begin{tabular}{|c|c|c|c|c|c|}
\hline \multirow{3}{*}{$\begin{array}{c}\text { Bróker } \\
\mathbf{N}^{\circ} \text { de Sesiones } \\
\end{array}$} & \multicolumn{2}{|c|}{ Without strategy } & \multicolumn{2}{|c|}{ With strategy } & \multirow{4}{*}{$\begin{array}{c}\text { Results } \\
\text { Graph }\end{array}$} \\
\hline & \multicolumn{2}{|c|}{ IQ Option } & \multicolumn{2}{|c|}{ IQ Option } & \\
\hline & \multicolumn{2}{|c|}{125} & \multicolumn{2}{|c|}{125} & \\
\hline Active & \multicolumn{2}{|c|}{ Criptomonedas } & \multicolumn{2}{|c|}{ Criptomonedas } & \\
\hline Time & \multicolumn{2}{|c|}{$30 \mathrm{~min}$} & \multicolumn{2}{|c|}{$30 \mathrm{~min}$} & \\
\hline \multirow{2}{*}{ Low Trend } & hit & not right & hit & not right & \\
\hline & 14 & 47 & 23 & 45 & \\
\hline Effectiveness\% & $11.2 \%$ & $37.6 \%$ & $18 \%$ & $36 \%$ & \\
\hline High Trend & 7 & 57 & 18 & 39 & \\
\hline Effectiveness $\%$ & $5.6 \%$ & $45.6 \%$ & $14 \%$ & $31 \%$ & \\
\hline \multicolumn{3}{|c|}{ Difference $\%$ with the strategy used } & $16.0 \%$ & $-16.0 \%$ & \\
\hline
\end{tabular}




\section{Conclusions}

The financial market offers great innovations for the dynamic and dynamic movement of transactions; therefore, it is necessary for investors to know the new alternatives that the market offers. The most important thing in investment is to take care of the risks since you cannot afford to lose a significant part of the capital. Not losing is more important than winning, because as long as it is not lost, you learn and keep the opportunities to win in the future.

Binary options are financial transactions; therefore, they require a broad knowledge to be able to operate with them. Trading in binary options is a virtual method in which you can make money in a short time and with a very low investment.

If you invest, you must buy when the price exceeds the central average. If this fluctuates between the central average and the central band, the purchase is maintained. If prices slide below the central average, it will have to be sold, since it is possible that the trend becomes bearish.

When choosing or opting for the assets with which it is going to operate, it is necessary that the investor knows or is familiar with them, since it can better deduce the fluctuation of prices they have within the market.

\section{References}

Aan, P. W. (1985). How RSI behaves. Enero: Revista Futures.

Alonso, D. (2014). Gestión [En línea]. Retrieved 12 de Febrero de 2018 from http://www.gestion.pe

Appel, G., \& Zweig, M. E. (1976). New directions in technical analysis. Great Neck, NY: Signalert.

Black, F., \& Scholes, M. (1972). The valuation of options contractsand a test of market efficiency. Journal of Finance, 27(2), 399-417.

Cofnas, A. (2016). Trading con opciones binarias. Bresca (Profit Editorial). ISBN 9788416583720

Costa, L. (1992). Nuevos Instrumentos financieros en la estrategia empresarial. Madrid : s.n.

Dotson, B. (2016). Opciones binarias: Createspace independent. California, USA: CreateSpace Independent Publishing.

Grazziano, J. (2015). Indicadores para derivados [En línea]. Retrieved 12 de febrero de 2018 from http://asociaciónmercadosfinancieros.com

Hull, J. (2004). Introducción a los mercados de futuros y opciones. España: Mc Graw-Hill.

Kauffman, P. J. (1998). Trading systems and methods. New Jersey, USA: Wiley.

Montero, M. (2014). La importancia de que las plataformas para opciones binarias sean reguladas. Barcelona: s.n.

Overby, B. (2009). The option playbook (2nd ed.). Florida, USA: Ally Invest.

Píngaro, A. M. (2016). Opciones Binanarias, Análisis y Estrategias. Buenos Aires: s.n.

Pring, M. J. (1991). Technical analysis explained. New York, NY, USA: McGraw-Hill Education.

Técnicas De Trading. (2016). [En línea]. Retrieved 12 de febrero de 2018 from http://www.tecnicasdetrading.com

Villamil, J. (2016). Modelos de Valoración de Opciones europeas en tiempo continuo. Cuadernos de Economia, 25(44).

White, H. (1987). The pricing options on assets with stochastic volatilies. Journal of finance, 42(2), 281-300.

Wilder, J. W. (1978). New concepts in technical trading systems. EE.UU: Ed. Trend Research.

Wilmott, P. (1995). The Mathematics of financial derivatives: A student introduction. Cambridge: Cambridge University Press. 